\title{
Micrococcus flavus sp. nov., isolated from activated sludge in a bioreactor
}

\author{
Xing-Yu Liu, ${ }^{1,2}$ Bao-Jun Wang, ${ }^{1}$ Cheng-Ying Jiang ${ }^{1}$ \\ and Shuang-Jiang Liu ${ }^{1}$ \\ ${ }^{1}$ State Key Laboratory of Microbial Resource, Institute of Microbiology, Chinese Academy of \\ Sciences, Zhong-Guan-Cun, Haidian, Beijing 100080, China \\ ${ }^{2}$ Graduate University of Chinese Academy of Sciences, Beijing 100049, China
}

\begin{abstract}
Bacterial strain $\mathrm{LW}^{\top}$ was isolated from activated sludge of a wastewater-treatment bioreactor. Cells of strain $L W 4^{\top}$ were Gram-positive cocci, with a diameter of 0.7-1.0 $\mu \mathrm{m}$. Colonies produced on LB agar plates were yellow, smooth, circular and $0.5-1.5 \mathrm{~mm}$ in diameter. Strain $\mathrm{LW} 4^{\top}$ was aerobic and grew over the temperature range $26-34{ }^{\circ} \mathrm{C}$ and $\mathrm{pH}$ range $5-9$, with optimal growth at $30.5-31.5^{\circ} \mathrm{C}$ and $\mathrm{pH} 6.0-6.2$. The cell-wall peptidoglycan of strain $\mathrm{LW} 4^{\top}$ contained amino acid residues of lysine, glutamic acid, alanine, glycine and aspartic acid. The most abundant cellular fatty acids of strain $\mathrm{LW} 4^{\top}$ were anteiso- $\mathrm{C}_{15: 0}(32.15 \%)$ and iso- $\mathrm{C}_{15: 0}(31.65 \%)$. Major respiratory quinones were $\mathrm{MK}-8\left(\mathrm{H}_{2}\right)(57.3 \%)$ and $\mathrm{MK}-7\left(\mathrm{H}_{2}\right)(32.9 \%)$. The DNA $\mathrm{G}+\mathrm{C}$ content was $71.4 \mathrm{~mol} \%\left(T_{\mathrm{m}}\right)$. 16S rRNA gene sequence analysis indicated that strain $\mathrm{LW}^{\top}$ was phylogenetically related to members of the genus Micrococcus, with similarities ranging from 96.5 to $97.3 \%$. Levels of DNA-DNA relatedness of strain LW4 ${ }^{\top}$ to Micrococcus luteus DSM $20030^{\top}$, Micrococcus lylae DSM $20315^{\top}$ and Micrococcus antarcticus AS $1.2372^{\top}$ were 55,48 and $36 \%$, respectively. Based on these results, it is concluded that strain LW4 ${ }^{\top}$ represents a novel species of the genus Micrococcus, for which the name Micrococcus flavus sp. nov. is proposed. The type strain is strain $\mathrm{LW}^{\top}{ }^{\top}\left(=\mathrm{CGMCC} 1.5361^{\top}=\mathrm{JCM} 14000^{\top}\right)$.
\end{abstract}

Since the first description of the genus Micrococcus by Cohn (1872), several emendations to this description have been made based on utilization of glucose, $\mathrm{G}+\mathrm{C}$ content of the genomic DNA and phylogenetic analysis of the 16S rRNA gene (detailed in Wieser et al., 2002). Although the genus comprises only three recognized species at the time of writing, Micrococcus luteus, Micrococcus lylae (Stackebrandt et al., 1995; Kloos et al., 1974) and Micrococcus antarcticus (Liu et al., 2000), the isolation and detection of Micrococcuslike bacteria from activated sludge have been reported repeatedly (Painter, 1983; Kataoka et al., 1996; Wieser et al., 2002). In this study, we report the isolation from activated sludge and the identification of a novel Micrococcus-like isolate, strain $\mathrm{LW}^{\mathrm{T}}$.

Bacterial strain $\mathrm{LW} 4^{\mathrm{T}}$ was isolated from activated sludge of a sequential batch reactor treating mixed wastewater of various nitroaromatic compounds (nitrobenzene, nitrophenol, 2,4-dinitrophenol) and aniline. The reactor had been operated for 1 year at the time when the sludge was sampled,

The GenBank/EMBL/DDBJ accession number for the 16S rRNA gene sequence of Micrococcus flavus LW4 ${ }^{\top}$ is DQ491453.

A scanning electron micrograph of cells of strain $L W 4^{\top}$ and a table detailing its cellular fatty acid composition are available as supplementary material in IJSEM Online. and the performance of the reactor was highly efficient (removal rates $\sim 99 \%$ ) in removing all nitroaromatic compounds and aniline. The sludge sample was suspended in sterile water by using vigorous vortexing, and a portion of the suspension was spread directly on LB agar plates. The plates were incubated at $30^{\circ} \mathrm{C}$ for about 1 week. Single colonies on the plates were picked up and bacterial strain $\mathrm{LW} 4^{\mathrm{T}}$ was obtained by repeatedly streaking the culture on new plates from a single colony.

Routine cultivation was conducted at $30^{\circ} \mathrm{C}$ with $\mathrm{LB}$ media. Gram reactions were determined according to the method described by Gerhardt et al. (1994). Cell motility and morphology were examined by transmission electron microscopy and scanning electron microscopy (see Supplementary Fig. S1 in IJSEM Online). Growth temperature range was determined with a $\mathrm{TN} 3 \mathrm{~F}$ temperature-gradient incubator (Advantec). Catalase and oxidase activities, the Voges-Proskauer reaction, aerobic production of acids from carbohydrates, carbon source utilization and other biochemical characterization were performed according to the methods of Barrow \& Feltham (1993) and Wieser et al. (2002).

Cells of strain $\mathrm{LW}^{\mathrm{T}}$ were Gram-positive cocci, with a diameter range of $0.7-1.0 \mu \mathrm{m}$. Flagella were not observed. 
Colonies were yellow, smooth, circular and $0.5-1.5 \mathrm{~mm}$ in diameter after 3 days cultivation on LB agar. Strain $\mathrm{LW}^{\mathrm{T}}$ was aerobic and grew over the temperature range $26-34{ }^{\circ} \mathrm{C}$ and $\mathrm{pH}$ range 5-9. Optimal growth was observed at 30.5-31.5 ${ }^{\circ} \mathrm{C}$ and $\mathrm{pH}$ 6.0-6.2. Strain $\mathrm{LW}^{\mathrm{T}}$ was not able to use nitrobenzene, nitrophenol, 2,4-dinitrophenol or aniline for growth. Additional physiological and biochemical properties of strain $\mathrm{LW} 4^{\mathrm{T}}$ are provided in the species description below.

Biomass for chemotaxonomic analyses was cultivated according to Stackebrandt et al. (1995) and at $30^{\circ} \mathrm{C}$ for $24 \mathrm{~h}$. Cell-wall analysis was performed according to the method described by Hasegawa et al. (1983). Cellular fatty acids were extracted, methylated and analysed by using the Sherlock Microbial Identification System following the manufacturer's instructions. Menaquinones were extracted and purified according to the method of Collins (1985) and were analysed by HPLC (Wu et al., 1989), with a previously characterized mixture of various menaquinones and ubiquinones (Hu et al., 2001) as a reference. The results indicated that the cell-wall peptidoglycan of strain $\mathrm{LW} 4^{\mathrm{T}}$ contained lysine, glutamic acid, alanine, glycine and aspartic acid. The most abundant cellular fatty acids of strain $\mathrm{LW} 4^{\mathrm{T}}$ were anteiso- $\mathrm{C}_{15: 0}(32.15 \%)$ and iso- $\mathrm{C}_{15: 0}$ $(31.65 \%)$, which were also found to be the dominant cellular fatty acids of other members of the genus Micrococcus (Wieser et al., 2002). However, a significant amount of iso- $\mathrm{C}_{15: 1}$ was detected in strain $\mathrm{LW}^{\mathrm{T}}(19.21 \%)$, compared with only trace amounts in other Micrococcus species (Wieser et al., 2002). Detailed information on the cellular fatty acid composition of strain $\mathrm{LW} 4^{\mathrm{T}}$ is provided in Supplementary Table S1. Strain $\mathrm{LW}_{4}^{\mathrm{T}}$ had MK-8 $\left(\mathrm{H}_{2}\right)(57.3 \%)$ as the major respiratory quinone, plus a significant of amount $\operatorname{MK}-7\left(\mathrm{H}_{2}\right)(32.9 \%)$.

DNA base composition was determined by thermal denaturation (Marmur \& Doty, 1962), with Escherichia coli K-12 as reference. The DNA G $+\mathrm{C}$ content of strain $\mathrm{LW}^{\mathrm{T}}$ was $71.4 \mathrm{~mol} \%$.

The nearly complete $16 \mathrm{~S}$ rRNA gene of strain $\mathrm{LW}^{\mathrm{T}}$ (1403 bp) was amplified and sequenced as described by Zhang et al. (2003). Alignments of 16S rRNA gene sequences were performed with the CLUSTAL_X program, version $1.64 \mathrm{~b}$ (Thompson et al., 1997). A neighbour-joining phylogenetic tree (Fig. 1) was constructed based on evolutionary distances that were calculated with the Kimura two-parameter model. Alignment positions with insertions or deletions were excluded from the calculations. 16S rRNA gene sequence analysis indicated that strain $\mathrm{LW}^{\mathrm{T}}$ was phylogenetically related to members of the genus Micrococcus, with similarities ranging from 96.5 to $97.3 \%$. The phylogenetic tree (Fig. 1) also indicated that strain $\mathrm{LW}^{\mathrm{T}}$ clustered with Micrococcus species and that this cluster was strongly supported (100\%).

Based on the above phenotypic and phylogenetic studies, it is clear that strain $\mathrm{LW} 4^{\mathrm{T}}$ represents a member of the genus Micrococcus. Strain $\mathrm{LW} 4^{\mathrm{T}}$ showed a range of phenotypic characteristics that differentiated it from recognized Micrococcus species (Table 1), such as the ability to reduce nitrate, assimilation of various carbon resources and major respiratory quinones. To distinguish strain $\mathrm{LW}^{\mathrm{T}}$ from other Micrococcus species further, levels of DNA-DNA relatedness of strain $\mathrm{LW} 4^{\mathrm{T}}$ to the type species of recognized Micrococcus species were determined by using the method described by Huß et al. (1983). Levels of DNA-DNA relatedness of strain $\mathrm{LW}^{\mathrm{T}}$ to $M$. luteus DSM $20030^{\mathrm{T}}, M$. lylae DSM $20315^{\mathrm{T}}$ and M. antarcticus AS $1.2372^{\mathrm{T}}$ were 55,48 and $36 \%$, respectively.

Based on the results presented here, it is concluded that strain $\mathrm{LW} 4^{\mathrm{T}}$ represents a novel species of the genus Micrococcus, for which the name Micrococcus flavus sp. nov. is proposed.

\section{Description of Micrococcus flavus sp. nov.}

Micrococcus flavus (fla'vus. L. masc. adj. flavus yellow, pertaining to the yellow colour of the colonies).

Cells are spherical, $0.7-1.0 \mu \mathrm{m}$ in diameter and non-motile. Gram-positive, aerobic and heterotrophic. Colonies are yellow, smooth and circular with entire margins. Optimal growth occurs at $30.5-31.5^{\circ} \mathrm{C}$ and $\mathrm{pH}$ 6-6.2. Catalase- and oxidase-positive. Starch is hydrolysed. Negative for the Voges-Proskauer reaction, lipase, reduction of nitrate and

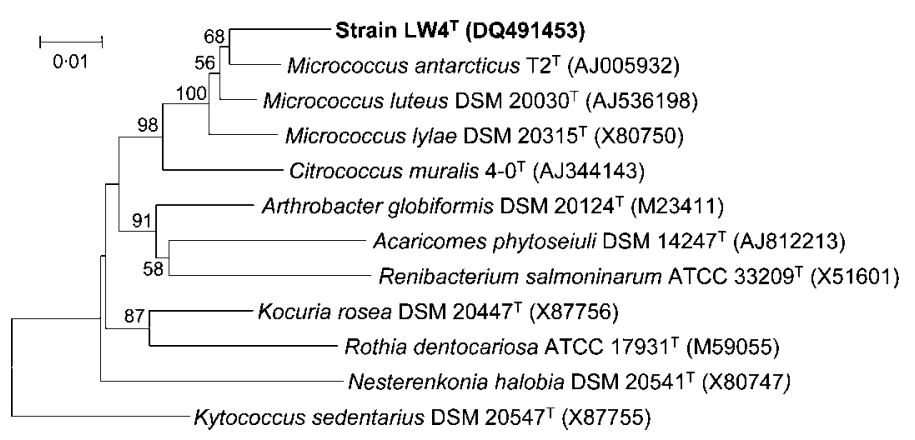

Fig. 1. Phylogenetic tree constructed with the neighbour-joining method according to 16S rRNA gene sequence evolutionary distance among strain $\mathrm{LW}^{\top}$ and the type strains of recognized members of the genus Micrococcus and type species of the family Micrococcaceae. Kytococcus sedentarius DSM $20547^{\top}$ was used as an outgroup. GenBank accession numbers are given in parentheses. Numbers represent confidence levels (values greater than $50 \%$ are shown) from 1000 replicate bootstrap samplings. Bar, evolutionary distance $\left(K_{\text {nuc }}\right)$ of 0.01 . 
Table 1. Phenotypic characteristics that differentiate strain $L W 4^{\top}$ from related Micrococcus species

Data for reference species were taken from Liu et al. (2000) and Wieser et al. (2002).

\begin{tabular}{|c|c|c|c|c|}
\hline Characteristic & Strain $\mathrm{LW}^{\mathrm{T}}$ & M. luteus & M. lylae & M. antarcticus \\
\hline Optimal growth temperature $\left({ }^{\circ} \mathrm{C}\right)$ & 31 & 37 & 37 & 16.8 \\
\hline Nitrate reduction & - & - & - & + \\
\hline Voges-Proskauer reaction & - & - & - & + \\
\hline Major quinone(s) & MK-8 $\left(\mathrm{H}_{2}\right), \mathrm{MK}-7\left(\mathrm{H}_{2}\right)$ & MK-8, MK-8 $\left(\mathrm{H}_{2}\right)$ & $\mathrm{MK}-8\left(\mathrm{H}_{2}\right)$ & MK-8, MK-8 $\left(\mathrm{H}_{2}\right)$ \\
\hline \multicolumn{5}{|l|}{ Hydrolysis of: } \\
\hline Tween 80 & - & - & - & + \\
\hline Starch & + & - & - & + \\
\hline \multicolumn{5}{|l|}{ Assimilation of: } \\
\hline D-Mannose & - & + & - & - \\
\hline L-Malate & - & - & - & + \\
\hline D-Trehalose & + & - & + & - \\
\hline DNA G $+C$ content $(\mathrm{mol} \%)$ & 71.4 & $70.0^{\star}$ & $69 \dagger$ & $66.4 \dagger$ \\
\hline
\end{tabular}

*Value for strain Ballarat determined by Wieser et al. (2002).

$\nmid$ Values for the type strains determined by Liu et al. (2000).

utilization of citric acid. Gelatin is not hydrolysed. No acid production from carbohydrates. Glycerol, trehalose and dextrin are used as carbon sources, but D-arabinose, fructose, mannitose, rhamnose, melibiose, xylitol, malic acid, L-glutamic acid, L-lactic acid, nitrilosides, L-arabinose, cellobiose, D-lactose, D-glucose, inositol, maltose, D-mannose, D-melibiose, raffinose, D-ribose, salicin and sorbitol are not. The predominant menaquinones are $\mathrm{MK}-8\left(\mathrm{H}_{2}\right)$ and MK-7 $\left(\mathrm{H}_{2}\right)$. The major cellular fatty acids are anteiso- $\mathrm{C}_{15: 0}$ $(32.15 \%)$ and iso- $\mathrm{C}_{15: 0}(31.65 \%)$. The $\mathrm{G}+\mathrm{C}$ content of the DNA is $71.4 \mathrm{~mol} \%\left(T_{\mathrm{m}}\right)$.

The type strain, $\mathrm{LW}^{\mathrm{T}}\left(=\mathrm{CGMCC} 1.5361^{\mathrm{T}}=\mathrm{JCM} 14000^{\mathrm{T}}\right.$ ), was isolated from activated sludge in a bioreactor.

\section{Acknowledgements}

This work was supported by grants from the National Natural Science Foundation of China (30230010) and Chinese Academy of Sciences (KSCX2-SW-113).

\section{References}

Barrow, G. I. \& Feltham, K. A. (1993). Cowan and Steel's Manual for the Identification of Medical Bacteria, 3rd edn. London: Cambridge University Press.

Cohn, F. (1872). Untersuchungen über Bakterien. Beitr Biol Pflanz 1, 127-244 (in German).

Collins, M. D. (1985). Isoprenoid quinone analysis in classification and identification. In Chemical Methods in Bacterial Systematics, pp. 267-287. Edited by M. Goodfellow \& D. E. Minnikin. London: Academic Press.
Gerhardt, P., Murray, R. G. E., Wood, W. A. \& Krieg, N. R. (1994). Methods for General and Molecular Bacteriology. Washington DC: American Society for Microbiology.

Hasegawa, T., Takizawa, M. \& Tanida, S. (1983). A rapid analysis for chemical grouping of aerobic actinomycetes. J Gen Appl Microbiol 29, 319-322.

Hu, H. Y., Lim, B. R., Goto, N. \& Fujie, K. (2001). Analytical precision and repeatability of respiratory quinones for quantitative study of microbial community structure in environmental samples. J Microbiol Methods 47, 17-24.

Huß, V. A. R., Festl, H. \& Schleifer, K. H. (1983). Studies on the spectrometric determination of DNA hybridization from renaturation rates. Syst Appl Microbiol 4, 184-192.

Kataoka, N., Tokiwa, T., Tanaka, Y., Takeda, K. \& Suzuki, T. (1996). Enrichment culture and isolation of slow growing bacteria. Appl Microbiol Biotechnol 45, 771-777.

Kloos, W. E., Tornabene, T. G. \& Schleifer, K. H. (1974). Isolation and characterization of micrococci from human skin, including two new species: Micrococcus lylae and Micrococcus kristinae. Int J Syst Bacteriol 24, 79-101.

Liu, H., Xu, Y., Ma, Y. \& Zhou, P. (2000). Characterization of Micrococcus antarcticus sp. nov., a psychrophilic bacterium from Antarctica. Int J Syst Evol Microbiol 50, 715-719.

Marmur, J. \& Doty, P. (1962). Determination of the base composition of deoxyribonucleic acid from thermal denaturation temperature. J Mol Biol 5, 109-118.

Painter, H. A. (1983). Metabolism and physiology of aerobic bacteria and fungi. In Ecological Aspects of Used-Water Treatment: Biological Activities and Treatment Processes, vol. 2, pp. 11-75. Edited by C. R. Curds \& H. A. Hawks. London: Academic Press.

Stackebrandt, E., Koch, C., Gvozdiak, O. \& Schumann, P. (1995). Taxonomic dissection of the genus Micrococcus: Kocuria gen. nov., Nesterenkonia gen. nov., Kytococcus gen. nov., Dermacoccus gen. nov., and Micrococcus Cohn 1872 emend. Int J Syst Bacteriol 45, 682-692.

Thompson, J. D., Gibson, T. J., Plewniak, F., Jeanmougin, F. \& Higgins, D. G. (1997). The CLUSTAL_X windows interface: flexible 
strategies for multiple sequence alignment aided by quality analysis tools. Nucleic Acids Res 25, 4876-4882.

Wieser, M., Denner, E. B. M., Kämpfer, P., Schumann, P., Tindall, B., Steiner, U., Vybiral, D., Lubitz, W., Maszenan, A. M. \& other authors (2002). Emended descriptions of the genus Micrococcus, Micrococcus luteus (Cohn 1872) and Micrococcus lylae (Kloos et al. 1974). Int J Syst Evol Microbiol 52, 629-637.
Wu, C., Lu, X. \& Qin, M. (1989). Analysis of menaquinone compound in microbial cells by HPLC. Microbiology [English translation of Microbiology (Beijing)] 16, 176-178.

Zhang, D., Yang, H., Zhang, W., Huang, Z. \& Liu, S.-J. (2003). Rhodocista pekingensis sp. nov., a cyst-forming phototrophic bacterium from a municipal wastewater treatment plant. Int J Syst Evol Microbiol 53, 1111-1114. 